\title{
Analisis Interaksi Genotipe x Lingkungan dan Stabilitas Galur Mutan Harapan Kacang Hijau [Vigna radiata (L.)]
}

\section{Genotype x Environment Interaction and Stability Analysis of Promising Mutant Lines of Mungbean [Vigna radiata (L.)]}

\author{
Yuliasti \\ Pusat Apalikasi Isotop dan Radiasi, BATAN \\ Jl. Lebak Bulus Raya No. 49 Jakarta 12440 \\ Email : upikyuliasti@yahoo.com
}

Diterima 02-12-2015; Diterima dengan revisi 25-02-2016; Disetujui 21-04-2016

\begin{abstract}
ABSTRAK
Analisis Interaksi Genotipe x Lingkungan dan Stabilitas Galur Mutan Harapan Kacang Hijau [Vigna radiata (L.)]. Analisis Interaksi genotipe $\times$ lingkungan merupakan salah satu langkah penting yang tepat untuk menduga kesesuaian genotipe galur mutan harapan kacang hijau dalam beradaptasi pada lingkungan yang beragam. Dalam penelitian ini, sembilan galur mutan harapan dan dua varietas kacang hijau di tanam di enam belas lokasi selama 2008- 2012 untuk menentukan stabilitas hasil biji dan kemampuan beradaptasi. Penelitian ini menggunakan rancangan acak kelompok dengan empat ulangan. Analisis gabungan untuk karakter hasil dilakukan mengikuti prosedur baku. Stabilitas hasil dan adaptasi hasil dianalisis dengan menggunakan koefisien regresi (bi), rata-rata hasil dan simpangan regresi oleh Finlay-Wilkinson dan metode Eberhart-Russell. Dari hasil penelitian ini, dapat disimpulkan bahwa galur mutan harapan kacang hijau PsJ S-31 memperlihatkan hasil yang tinggi $(2,47$ ton/ha), dan diklasifikasikan sebagai galur yang stabil dengan metode analisis stabilitas Finlay-Wilkinson, Eberhart - Russel. PsJS-31 dapat direkomendasikan kepada petani berdasarkan pada keragaan stabilitas dan potensi hasil tinggi selama seleksi. Mutan PsJS-31 telah dirilis sebagai varietas baru pada tahun 2013 dengan nama Muri.
\end{abstract}

Kata kunci : Interaksi G x E dan stabilitas hasil, menjanjikan galur mutan kacang hijau

\begin{abstract}
Genotype $x$ Environment Interaction and Stability Analysis of Promising Mutant Lines of Mungbean [Vigna radiata (L.)]. This assessing of genotype $\times$ environment interaction was one important step for accurate mungbean promisng mutan lines evaluation in large multi-environment trials. In this study, nine promising mutant lines and two mungbean varieties were grown in sixteen environments during 2008-2012 plant season to determine the grain yield stability and adaptability. The experiment used randomized complete block design with four replications. A combined analysis of variance for yield was performed following a standard method. Yield stability and adaptability of yield performance were analyzed by using coefficient regression (bi), general mean of yield and deviation of regression by FinlayWilkinson and Eberhart-Russell method. From the current study, it is concluded that among mungbean promising mutant lines. The mutant promising PsJ S-31 were stable for two stability parameters and combination with high yield potential $(2,47$ ton/ha), that could be recommended to farmers based on their performance of stability and high yield potential during selection. The mutant PsJS-31 had been released as new varieties in 2013. The name is Muri.
\end{abstract}

Keywords : G x E interaction and Yield stability, promising mungbean mutant lines 


\section{PENDAHULUAN}

Kacang hijau [Vigna radiata (L.)] merupakan tanaman legum yang sangat penting di Indonesia setelah kedelai. Seiring dengan pertambahan jumlah penduduk Indonesia, kebutuhan kacang hijau juga meningkat sekitar $4 \%$ per tahun, sedangkan luas lahan panen pada tahun 2012 berkurang 5,68\% dari tahun 2011 menjadi 254.101 ha. Sementara produksi nasional berkurang 2\%, dari 341.000 ton menjadi 295.904 ton pada tahun 2012 [1]. Kacang hijau tidak hanya sebagai sumber protein tapi juga dapat meningkatkan organik tanah melalui fiksasi nitrogen [2]. Kekurangan produksi tersebut harus dipenuhi antara lain dengan menanam varietas unggul.

Perbaikan genetik tanaman dapat dilakukan menggunakan berbagai metode dalam pemuliaan tanaman, antara lain induksi mutasi dan hibridisasi. Penelitian pemuliaan mutasi pada tanaman pertanian pada umumnya menggunakan radiasi gamma [3] karena radiasi gamma mempunyai daya tembus yang lebih dalam pada target sel dari material tanaman yang digunakan untuk radiasi. Frekuensi dan spektrum mutasi yang ditimbulkan akan sangat ditentukan oleh dosis iradiasi gamma dan laju dosis yang digunakan [4]. Induksi mutasi dapat dilakukan dengan menggunakan mutagen kimia dan fisik. Iradiasi sinar gamma merupakan salah satu jenis mutagen fisik yang biasa digunakan untuk meningkatkan keragaman genetik pada berbagai tanaman. Perlakuan mutagen akan merusak DNA dan selama proses perbaikan DNA akan terjadi mutasi baru yang diinduksi secara acak. Perubahan dapat terjadi pada organel di sitoplasma maupun mutasi kromosom inti [5]. Menurut laporan International Atomic Energy Agency (IAEA) pada tahun 2003 diketahui bahwa sekitar 326 mutan varietas padi dihasilkan melalui radiasi gamma dengan sumber $\mathrm{Co}^{60}$. Keragaman genetik sebagai akibat dari mutasi dapat diidentifikasi secara morfologi, agronomi, dan molekuler. Hasil identifikasi keragaman genetik dengan molekuler menunjukkan tingkat lokus yang polimorfis meningkat secara signifikan pada mutan kedelai yang diberi 200 Gy iradiasi sinar gama, dibandingkan dengan yang tidak di radiasi (kontrol) [6]. Galur mutan PsJS-31 adalah produk dari pemuliaan mutasi dengan menggunakan iradiasi sinar gamma pada varietas Gelatik $150 \mathrm{Krad}$ [7].

Suatu galur harapan kacang hijau untuk dapat dilepas sebagai varietas unggul memerlukan tahap pengujian potensi genetik dari setiap galur harapan pada berbagai sentra produksi kacang hijau melalui uji adaptasi. Lingkungan uji adaptasi penting ditentukan agar lingkungan uji adaptasi mewakili lingkungan produksi [8]. Dalam uji adaptasi dari sejumlah galur harapan di lintas lokasi hampir selalu terdapat interaksi antara galur dengan lingkungan lgenotype $\times$ environment [9]. Interakasi genotipe dengan lingkungan (GXE) terjadi jika genotipe memperlihatkan respon yang berbeda pada kondisi lingkungan yang berbeda. Interaksi genotipe dengan lingkungan dikelompokkan menjadi dua yaitu interaksi yang bersifat quantitatif dan interaksi yang bersifat qualitatif [10]. Interaksi genotipe dengan lingkungan yang bersifat quantitatif tidak menyebabkan probahan rangking genotipe. Genotipe yang unggul pada satu lingkungan tetap unggul pada lingkungan yang berbeda. Interaksi kualitatif sebagai suatu interaksi genotipe $\mathrm{x}$ lingkungan ditunjukkan oleh adanya perubahan ranking suatu genotipe pada setiap lokasi uji [11]. Informasi tentang $\mathrm{G} x$ $\mathrm{E}$ dari galur yang telah dihasilkan sangat diperlukan ketika suatu varietas akan dirilies.

Berdasarkan hasil analisis G x E, suatu galur dapat direkomendasikan jadi varietas stabil dan berdaya adaptasi luas atau varietas beradaptasi sepesifik untuk lokasi tertentu. Ketika interaksi genotipe dan lingkungan bersifat kualitatif (crossover interaction), pemulia harus memilih satu genotipe untuk lingkungan tertentu dan genotipe lain untuk lingkungan yang berbeda [12]. Kondisi ini akan menimbulkan kesulitan dalam memilih genotipe yang 
stabil sehingga perlu dilakukan analisis stabilitas. Analisis stabilitas dilakukan untuk mengurai pengaruh interaksi genotipe dan lingkungan secara efektif serta dapat memilah genotipe-genotipe yang stabil dan spesifik [13].

Stabilitas hasil adalah salah satu sifat paling diinginkan dari genotipe yang akan dilepas menjadi varietas nasional. Penelitian terhadap interaksi genotipe dengan lingkungan dan stabilitas hasil adalah penting untuk mengevaluasi konsistensi daya hasil suatu genotipe seperti galur mutan harapan pada berbagai faktor lingkungan. Penelitian bertujuan untuk mengetahui adaptabilitas dan stabilitas sembilan galur mutan kacang hijau.
Tengah), Bogor (Jawa Barat), Jambi, Kampar (Riau), Goa (Sulawesi Selatan), Ternate (Maluku), Sleman (Yogyakarta), Pangkajene (Sulsel), Randu Agung (Jatim), Bantul (Yogyakarta).

Materi genetik yang digunakan terdiri dari 10 galur mutan harapan kacang hijau M7 yaitu PsJ S-30, PsJ S-31, PsJ S-32, PsJ-6, PsJ-19, PsJ-21，PsJ-BII-17，PsJ-BII-5，PsJ-BII15. Galur-galur ini berasal dari iradiasi sinar Gamma varietas Gelatik dengan dosis 200 Gy. Varitas Perkutut dan Gelatik digunakan sebagai pembanding.

Rancangan percobaan yang digunakan di setiap lokasi penelitian adalah rancangan acak kelompok dengan 11 perlakuan dan empat ulangan. Ukuran petak $4 \mathrm{~m} \times 5 \mathrm{~m}$,

Tabel 1. Deskripsi lokasi uji adaptasi galur harapan kacang

\begin{tabular}{clllc}
\hline No. & \multicolumn{1}{c}{ Lokasi } & \multicolumn{1}{c}{$\begin{array}{c}\text { Musim } \\
\text { tanam }\end{array}$} & Jenis tanah & $\begin{array}{c}\text { Tinggi tempat } \\
\text { (m dpl) }\end{array}$ \\
\hline 1 & Boyolali - Jateng & MK II 2009 & Alluvial & 110 \\
2 & Kampung Solok - Jambi & MK II 2008 & PMK & 105 \\
3 & Kampar - Riau & MK II 2008 & PMK & 102 \\
4 & Bantul - Yogyakarta & MK II 2009 & Latosol & 110 \\
5 & Jambe G, Malang-Jatim & MK II 2011 & Regosol & 113 \\
6 & Muneng - Jatim & MK II 2011 & Alvisol & 113 \\
7 & Ternate - Ambon & MK II 2012 & Alluvial & 127 \\
8 & Pangkajene - Sulsel & MK II 2012 & Regosol & 119 \\
9 & Bima - NTB & MK II 2011 & PMK & 119 \\
10 & Lombok Timur - NTB & MK II 2010 & Alluvial & 116 \\
11 & Goa - Sulsel & MH 2008 & Regosol & 120 \\
12 & Pasuruan - Jatim & MH 2011 & Latosol & 113 \\
13 & R A Malang - Jatim & MH 2010 & Latosol & 113 \\
14 & Nermada - NTB & MH 2008 & Grumusol & 116 \\
15 & Citayam - Jabar & MH 2008 & Aluvial & 107 \\
16 & Sleman - Yogyakarta & MH 2010 & Latosal & 110 \\
\hline
\end{tabular}

\section{BAHAN DAN METODE}

Uji adaptasi telah dilakukan mulai tahun 2008 sampai dengan tahun 2012 di lahan sawah dan lahan tegalan yang tersebar di beberapa propinsi di Indonesia yaitu: Lombok Timur (Nusa Tenggara Barat), Bima (Nusa Tenggara Barat), Nermada (Nusa Tenggara Barat), Malang (Jawa Timur), Muneng Probolinggo (Jawa Timur), Pasuruan (Jawa Timur), Boyolali (Jawa jarak tanam $40 \mathrm{~cm} \times 20 \mathrm{~cm}$, dua biji per lobang. Pemupukan dengan $50 \mathrm{~kg}$ Urea, 100 $\mathrm{kg}$ SP36 dan $75 \mathrm{~kg} \mathrm{KCl}$ per ha diberikan secara sebar merata sebelum tanam. Pengendalian gulma dilakukan pada umur 2 dan 4 minggu setelah tanam. Peubah yang diamati adalah Parameter pengamatan meliputi: tinggi tanaman, umur masak, jumlah polong, hasil biji kering, bobot 100 biji, panjang polong. Pemupukan dengan Urea $50 \mathrm{~kg} / \mathrm{ha}$, SP36 $100 \mathrm{~kg} / \mathrm{ha}$ dan $\mathrm{KCl} 75$ 
$\mathrm{kg}$ /ha diberikan secara larikan. Perawatan benih (seed treatment) dengan insektisida 'Marshal'. Pengolahan tanah, pengendalian gulma, hama dan penyakit dilakukan secara optimal.

Analisis gabungan (combined analysis overlocation) menggunakan software SAS 9, dilakukan terhadap hasil biji dari 11 genotip kacang hijau di 16 lokasi penelitian. Jika dalam analisis ragam gabungan terdapat interaksi antara galur (genotipe $=\mathrm{G}$ ) x Lokasi (lingkungan $=\mathrm{E}$ ) yang nyata, maka diteruskan dengan analisis stabilitas hasil menurut Finlay dan Wilkinson, 1963 [14].

FINLAY dan WILKINSON (1963) memberikan panduan penilaian adaptabilitas suatu genotipe yang didasarkan atas nilai koefisien regresi (bi) dan rata-rata hasilnya. Genotipe dengan nilai koefisien regresi (bi) < 1 berarti genotipe memiliki stabilitas di atas rata-rata, genotipe beradaptasi khusus di lingkungan yang produktivitasnya rendah dan kurang peka terhadap perubahan lingkungan, artinya dengan adanya perubahan lingkungan, genotipe hanya memberikan sedikit perubahan terhadap hasil. Nilai bi $>1$ artinya genotipe memiliki stabilitas di bawah rata-rata dan beradaptasi khusus di lingkungan yang produktivitasnya tinggi, sedangkan nilai bi $=1$ dan genotipe memiliki rata-rata hasil di atas rata-rata umum berarti genotipe yang demikian beradaptasi baik pada semua lingkungan. Nilai bi $=1$ dan genotipe memiliki rata-rata hasil di bawah rata-rata umum berarti genotipe tersebut tidak beradaptasi baik pada semua lingkungan dan peka terhadap perubahan lingkungan.

Koefisien respon terhadap lingkungan pada dasarnya merupakan nilai pembagian antara covariance nilai rata-rata produksi masing-masing genotipe dan indeks lingkungan dengan indeks lingkungannya. Secara manual nilai bi dihitung sebagai berikut :

bi $=\frac{\sum(Y i j-\bar{Y} i .)(\bar{X} . j-\bar{X} . .)}{\sum(\bar{X} i j-\bar{X} . .)^{2}}$

dimana Yij adalah nilai rata-rata produksi masing-masing genotipe pada masing-masing lingkungan; Yi. adalah nilai rata-rata produksi pada lingkungan tertentu; Xij adalah indeks lingkungan; dan $\mathrm{X}$ adalah rata-rata seluruh indeks lingkungan.

\section{HASIL DAN PEMBAHASAN}

\section{Interaksi genetik dan lingkungan (GXE)}

Analisis ragam gabungan dilakukan terhadap hasil untuk mengetahui pengaruh genotipe terhadap lingkungan, dan interaksi genetik dengan lingkungan terhadap hasil. Faktor genetik dan lingkungan serta interaksi $\mathrm{GxE}$ berpengaruh sangat nyata dengan hasil biji galur galur mutan kacang hijau (Tabel 2).

Tabel 2. ${ }^{*}$ Sidik ragam analisis gabungan terhadap hasil $(\mathrm{t} / \mathrm{ha})$

\begin{tabular}{lccccc}
\hline \multicolumn{1}{c}{ Sumber } & Derajat bebas & Jumlah kuadrat & Kuadrat tengah & F hit & Pr $>$ F \\
\hline Genotip & 10 & 22,91 & 2,29 & $30,32^{* *}$ & $<, 0001$ \\
Lokasi & 15 & 175,97 & 11,73 & $155,23^{* *}$ & $<, 0001$ \\
G x E & 150 & 61,03 & 0,47 & $5,38^{* *}$ & $<, 0001$ \\
Ulangan (Lokasi) & 48 & 4,23 & 0,09 & $1,17^{*}$ & 0,2139 \\
Galat & 480 & 36,27 & 0,08 & & \\
Total & 703 & 300,42 & & & \\
\hline
\end{tabular}

\footnotetext{
$\mathrm{KK}(\%) \quad=13,15$

Keterangan: * ${ }^{*} \quad$ berbeda nyata pada taraf $\alpha 5 \%$

$*^{*} \quad=$ berbeda nyata pada taraf $\alpha 1 \%$,

$\mathrm{KK}=$ koefisien keragaman
} 
Dugaan komponen ragam lingkungan yang bernilai besar menunjukkan bahwa dari 16 lokasi yang digunakan memperlihatkan ragam karakter agroekologi yang berbeda-beda. Pengaruh galur yang nyata mengindikasikan terdapatnya perbedaan komposisi dan potensi genetik
Selain itu, latar belakang genetik dari sembilan galur harapan yang diuji bersumber pada komposisi genetik yang sama, semuanya merupakan hasil seleksi keturunan dari varietas Gelatik sehingga perbedaan genetik antar galur relatif hampir serupa.

Tabel 3. Hasil Analisis Ragam produksi biji kering dan karakter agronomi di 16 lokasi

\begin{tabular}{lcccc}
\hline \multirow{2}{*}{ Karakter } & \multicolumn{3}{c}{ Ragam } & \multirow{2}{*}{ KK $(\%)$} \\
\cline { 2 - 4 } & Lokasi $(\mathrm{E})$ & Genotipe $(\mathrm{G})$ & $\mathrm{GXE}$ & 13.25 \\
\hline Hasil (t/ha) & 0.019 & 0.035 & 0.10 & 8.7 \\
Tinggi tanaman (cm) & 6.22 & 5.16 & 30.77 & 1.62 \\
Umur masak (hr) & 0.24 & 1.76 & 30.15 & 16.01 \\
Jumlah polong (cm) & 1.67 & 0.29 & 3.62 & 10.29 \\
Panjang Polong & 6.25 & 0.19 & 1.97 & 4.68 \\
Berat 100 biji & 0.03 & 0.16 & 0.43 & \\
\hline
\end{tabular}

dari setiap galur yang diuji. Interaksi $\mathrm{G} \times \mathrm{E}$ yang nyata menujukkan bahwa masingmasing galur harapan memiliki tanggap spesifik terhadap kualitas lingkungan tertentu (Tabel 2).

Hasil data kuadrat tengah produksi yaitu genotip, lokasi (lingkungan $=\mathrm{E}$ ) dan interaksi genotip dengan lingkungan (Tabel 2). Pengaruh genotipe yang sangat nyata mengindikasikan terdapatnya perbedaan nilai tengah hasil antara genotipe galur yang diuji. Interaksi $G \times E$ yang sangat nyata menunjukkan masing-masing galur memiliki hasil yang berbeda pada lingkungan yang berbeda. Interaksi genotipe $\mathrm{x}$ lingkungan disebabkan adanya perubahan respon dari setiap genotipe yang diuji pada setiap lingkungan [15].

Pengujian sembilan galur mutan harapan kacang hijau ditambah dua varietas pembanding dilakukan di 16 lokasi sentra produksi kacang hijau di Indonesia. Pada penelitian ini diperoleh dugaan komponen ragam $\mathrm{G} \times \mathrm{E}$ lebih besar dibandingkan dengan dugaan ragam genotip dan lingkungan (Tabel 3). Hal ini menunjukkan bahwa faktor interaksi genetik dengan lingkungan, memiliki peran penting dalam menentukan potensi hasil biji kacang hijau.
Berdasarkan hasil analisis sidik ragam gabungan untuk produksi dan sifat Agronomi galur mutan kacang hijau antara lain [tinggi tanaman $(\mathrm{cm})$, umur masak $(\mathrm{hr})$, jumlah polong $(\mathrm{cm})$, panjang polong, berat 100 biji] terlihat bahwa genotipe, lokasi dan interaksi antara keduanya berpengaruh sangat nyata terhadap semua peubah yang diamati (Tabel 4). Hasil ini menunjukkan bahwa hasil biji kering dan sifat Agronomi galur mutan kacang hijau dipengaruhi oleh faktor genetik (jenis galur yang ditanam), lingkungan (lokasi) dan interaksi antara genotipe dan lingkungan. Rasyad dan Idwar (2010) [16] melaporkan bahwa interaksi G x $\mathrm{E}$ berpengaruh nyata pada jumlah polong dan hasil biji per plot pada kedelai. Adanya peran interaksi $\mathrm{G} \times \mathrm{E}$ yang lebih besar dari galur mengindikasikan terdapatnya perbedaan respon galur terhadap lingkungan [17].

Dengan demikian potensi hasil galur mutan kacang hijau bergantung pada kondisi lingkungan/lokasi dan jenis galur (genotipe) yang ditanam. Interaksi galur $\times$ lingkungan yang rendah memberikan dampak langsung terhadap stabilitas hasil suatu galur. Berdasarkan Nilai tengah karakter hasil biji kering galur mutan kacang hijau 
Tabel 4. Hasil Analisis Sidik ragam hasil biji kering dan karakter agronomi di 16 lokasi

\begin{tabular}{lrcrc}
\hline \multirow{2}{*}{ Karakter } & \multicolumn{3}{c}{ Nilai Tengah (KT) } & \multirow{2}{*}{ KK (\%) } \\
\cline { 2 - 4 } & Lokasi (E) & Genotipe $(\mathrm{G})$ & \multicolumn{1}{c}{ GxE } & \\
\hline Hasil (t/ha) & $11.22^{* *}$ & $2.29^{* *}$ & $0.46^{* *}$ & 13.25 \\
Tinggi tanaman $(\mathrm{cm})$ & $13406.39^{* *}$ & $355.38^{* *}$ & $148.66^{* *}$ & $\mathbf{8 . 7}$ \\
Umur masak $(\mathrm{hr})$ & $4526.28^{* *}$ & $113.78^{* *}$ & $121.56^{* *}$ & 1.62 \\
Jumlah polong $(\mathrm{cm})$ & $1647.86^{* *}$ & $25.48^{* *}$ & $21.15^{* *}$ & 16.01 \\
Panjang Polong & $135.79^{* *}$ & $36.97^{* *}$ & $32.87^{* *}$ & 10.29 \\
Berat 100 biji & $34.74^{* *}$ & $10.84^{* *}$ & $1.82^{* *}$ & 4.68 \\
\hline
\end{tabular}

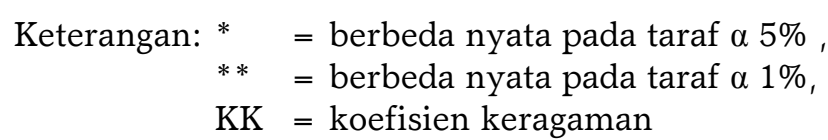

memberikan hasil Interaksi galur dengan lingkungan yang rendah dibandingkan dengan sifat Agronomi (Tabel 4). Interaksi genotipe dan lingkungan tumbuh kacang hijau juga dilaporkan oleh Asfaw et al. (2012) [18] dan Trustinah (2013) [19]. Hasil yang sama juga dikemukakan oleh Hermiati et al., (1990) [20] pada kacang tanah. Berdasarkan hasil penelitian pada kedelai: genotipe, lingkungan, dan interaksi genotipe $\mathrm{x}$ lingkungan berpengaruh nyata terhadap jumlah polong per tanaman; tinggi tanaman, jumlah cabang per tanaman, umur berbunga dan hasil biji serta bobot 100 biji [21]. Adanya interaksi genotipe $x$ lingkungan menunjukkan perbedaan adaptasi dan stabilitas dari masing-masing galur [22]. Jika dilihat dari nilai tengah yang diberikan oleh masing-masing karakter terlihat bahwa pengaruh lokasi (lingkungan) merupakan penyumbang terbesar, kemudian disusul oleh pengaruh genotipe dan pengaruh interaksi genotipe dan lingkungan untuk semua karakter yang diamati (Tabel 4).

Tabel 5 menunjukkan indeks lingkungan (IJ) dari hasil uji adaptasi di enam belas lokasi. Ij merupakan dasar untuk mengukur produktivitas lingkungan, semakin tinggi nilai $\mathrm{Ij}$ menunjukkan lingkungan bersangkutan paling produktif dalam menghasilkan hasil biji dan sebaliknya.

Tabel 5. Rerata produktivitas semua genotipe dan indeks Lingkungan di setiap lokasi

\begin{tabular}{clcc}
\hline No. & \multicolumn{1}{c}{ Lokasi } & Rerata hasil biji kering $(\mathrm{t} / \mathrm{ha})$ & Indeks lingkungan $(\mathrm{Ij})$ \\
\hline 1 & Boyolali - Jateng & $1,34 \mathrm{~h}$ & $-0,75$ \\
2 & Kp Solok - Jambi & $1,54 \mathrm{~g}$ & $-0,55$ \\
3 & Kampar - Riau & $1,49 \mathrm{~g}$ & $-0,59$ \\
4 & Bantul - Yogyakarta & $1,64 \mathrm{f}$ & $-0,44$ \\
5 & Jambe Gede - Jatim & $2,65 \mathrm{ab}$ & 0,57 \\
6 & Muneng - Jatim & $1,48 \mathrm{~g}$ & $-0,61$ \\
7 & Ternate - Ambon & $2,55 \mathrm{ab}$ & 0,47 \\
8 & Pangkajene - Sulsel & $2,02 \mathrm{e}$ & $-0,06$ \\
9 & Bima - NTB & $2,52 \mathrm{~b}$ & 0,43 \\
10 & Lombok Timur - NTB & $2,66 \mathrm{a}$ & 0,57 \\
11 & Goa - Sulsel & $2,04 \mathrm{e}$ & $-0,04$ \\
12 & Pasuruan - Jatim & $2,54 \mathrm{~b}$ & 0,45 \\
13 & Randu Agung - Jatim & $1,55 \mathrm{~g}$ & $-0,51$ \\
14 & Nermada - NTB & $2,68 \mathrm{a}$ & 0,59 \\
15 & Citayam - Jabar & $2,26 \mathrm{~d}$ & 0,18 \\
16 & Sleman - Yogyakarta & $2,46 \mathrm{c}$ & 0,37 \\
\hline Rerata & & 2,09 & 0,00 \\
\hline
\end{tabular}


Nilai indeks lingkungan digunakan untuk menduga tingkat produktivitas relative satu lokasi terhadap komoditas tertentu [23]. Hasil penelitian menunjukkan bahwa Narmada, lombok Timur dan Jambe Gede mempunyai kondisi lingkungan yang relatif cocok untuk tanaman kacang hijau dan dapat dimanfaatkan untuk budi daya kacang hijau, dengan nilai $\mathrm{Ij},(+0,59)$, $(+0,57)$, Ij yang positif relatif lebih cocok buat tanaman kacang hijau dari pada Ij negatif, serta memberikan rata-rata hasil genotype 2,$68 ; 2,66$ dan 2,65 ton/ha (Tabel 5). Lokasi dengan indeks lingkungan tinggi (tingkat kesuburan tinggi) akan mempunyai rata-rata produktivitas tinggi. Sebaliknya lokasi dengan indeks lingkungan relatif rendah (tingkat kesuburan rendah) akan mempunyai rata-rata hasil rendah [24].
Interaksi $\mathrm{G} \times \mathrm{E}$ yang nyata, menunjukkan urutan keunggulan relatif dari sebelas galur mutan berubah-ubah pada 16 lokasi penelitian. Sebagai contoh, galur terbaik pada lokasi Lombok Tim Jambe Gede (Malang) adalah Psj S 30 (G1) 2.9 t/h dan pada lokasi Muneng (Probolinggo) 1.9 $\mathrm{t} / \mathrm{h}$. Galur PsJ S 31 adalah galur berdaya hasil tertinggi mampu memiliki rata-rata hasil hingga $2.47 \mathrm{t} / \mathrm{ha}$, dibandingkan delapan galur lainnya (Tabel 6). Galur PsJ S 31 berdaya hasil tinggi dan relatif tidak mengalami fluktuasi hasil pada berbagai lingkungan berpeluang untuk menjadi varietas yang stabil

\section{Stabilitas hasil biji}

Dua galur mutan kacang hijau (PsJ S 31 dan PsJ S32) kacang hijau ternyata

Tabel 6. Hasil biji kering dari sembilan galur harapan kacang hijau dan dua varietas pembanding di Enam belas Lokasi

\begin{tabular}{|c|c|c|c|c|c|c|c|c|c|c|c|c|}
\hline \multirow{2}{*}{ No } & \multirow{2}{*}{ Lokasi } & \multicolumn{11}{|c|}{ Hasil Biji Ton/ha } \\
\hline & & G1 & G2 & G3 & G4 & G5 & G6 & G7 & G8 & G9 & G10 & G11 \\
\hline 1 & Boyolali & $1.2 \mathrm{~b}$ & $1.6 \mathrm{a}$ & $1.3 \mathrm{~b}$ & $1.3 \mathrm{c}$ & $1.4 \mathrm{~b}$ & $1.2 \mathrm{~b}$ & $1.3 \mathrm{~b}$ & $1.3 \mathrm{~b}$ & $1.6 a b$ & $1.4 \mathrm{~b}$ & $1.2 \mathrm{~b}$ \\
\hline 2 & Jambi & $1.6 \mathrm{~b}$ & $3.3 a$ & $1.7 \mathrm{c}$ & $1.3 \mathrm{c}$ & $1.4 \mathrm{~b}$ & $1.4 \mathrm{~b}$ & $1.2 \mathrm{~b}$ & $1.7 \mathrm{~b}$ & $1.5 \mathrm{~b}$ & $0.3 \mathrm{c}$ & $1.3 \mathrm{c}$ \\
\hline 3 & Riau & $1.8 \mathrm{a}$ & $1.7 \mathrm{~b}$ & $1.5 \mathrm{c}$ & $1.4 \mathrm{~b}$ & $1.9 \mathrm{a}$ & $0.6 \mathrm{~b}$ & $2.0 \mathrm{a}$ & $1.1 \mathrm{c}$ & $1.4 \mathrm{~b}$ & $1.2 \mathrm{c}$ & $1.9 \mathrm{a}$ \\
\hline 4 & Bantul & $2.4 \mathrm{~b}$ & $2.7 \mathrm{a}$ & $2.3 \mathrm{c}$ & $2.4 \mathrm{c}$ & $2.4 \mathrm{c}$ & $2.5 \mathrm{c}$ & $2.6 \mathrm{~b}$ & $2.4 \mathrm{c}$ & $2.2 \mathrm{c}$ & $2.4 \mathrm{c}$ & $2.4 \mathrm{c}$ \\
\hline 5 & $\begin{array}{l}\text { Jambe Gede } \\
\text { Malang }\end{array}$ & $2.9 \mathrm{a}$ & $1.8 \mathrm{~b}$ & $1.3 \mathrm{c}$ & $1.2 \mathrm{c}$ & $1.4 \mathrm{bc}$ & $1.3 \mathrm{c}$ & $1.4 \mathrm{bc}$ & $1.4 \mathrm{~b}$ & $1.5 \mathrm{bc}$ & $1.6 \mathrm{~h}$ & $1.5 \mathrm{bc}$ \\
\hline 6 & Muneng & $1.9 \mathrm{c}$ & $3.3 \mathrm{a}$ & $3.3 \mathrm{a}$ & $3.0 \mathrm{ab}$ & $3.1 \mathrm{a}$ & $2.8 \mathrm{ab}$ & $1.8 \mathrm{c}$ & $2.5 \mathrm{~b}$ & $3.2 \mathrm{ab}$ & $2.6 \mathrm{~b}$ & $2.5 b$ \\
\hline 7 & Ternate & $2.6 \mathrm{ab}$ & $2.7 \mathrm{a}$ & $2.4 \mathrm{~b}$ & $2.5 \mathrm{c}$ & $2.3 \mathrm{e}$ & $2.5 \mathrm{~cd}$ & $2.5 \mathrm{~b}$ & $2.6 a b$ & $2.7 \mathrm{ab}$ & $2.6 a b$ & $2.4 \mathrm{c}$ \\
\hline 8 & $\begin{array}{l}\text { Pangka } \\
\text { Jene(Sulsel) }\end{array}$ & $1.9 \mathrm{~d}$ & $3.0 \mathrm{a}$ & $2.96 \mathrm{a}$ & $2.3 \mathrm{c}$ & $2.9 \mathrm{a}$ & $2.1 \mathrm{c}$ & $2.6 a b$ & $2.2 \mathrm{c}$ & $2.6 a b$ & $2.3 \mathrm{~b}$ & $2.2 \mathrm{c}$ \\
\hline 9 & Bima & $2.4 \mathrm{ab}$ & $2.9 \mathrm{a}$ & $2.8 \mathrm{ab}$ & $2.4 \mathrm{~b}$ & $2.9 \mathrm{a}$ & $3.0 \mathrm{a}$ & $2.4 \mathrm{c}$ & $2.8 \mathrm{a}$ & $3.0 \mathrm{a}$ & $1.9 \mathrm{~d}$ & $2.4 \mathrm{c}$ \\
\hline 10 & $\begin{array}{l}\text { Lombok } \\
\text { Timur }\end{array}$ & $2.7 \mathrm{ab}$ & $3.3 \mathrm{a}$ & $2.8 \mathrm{ab}$ & $2.6 a b$ & $2.9 \mathrm{a}$ & $3.0 \mathrm{a}$ & $2.4 \mathrm{~b}$ & $2.8 \mathrm{ab}$ & $3.0 \mathrm{a}$ & $1.9 \mathrm{c}$ & $2.4 \mathrm{~b}$ \\
\hline 11 & Goa (Sulse) & $1.9 \mathrm{~d}$ & $2.3 \mathrm{~b}$ & $2.5 \mathrm{a}$ & $2.2 \mathrm{c}$ & $2.2 \mathrm{c}$ & $1.9 \mathrm{~d}$ & $1.8 \mathrm{e}$ & $2.3 \mathrm{c}$ & $1.8 \mathrm{e}$ & $1.8 \mathrm{f}$ & $1.6 \mathrm{~g}$ \\
\hline 12 & $\begin{array}{l}\text { Randu } \\
\text { Agung }\end{array}$ & $1.8 \mathrm{a}$ & $1.5 \mathrm{~b}$ & $2.6 \mathrm{~b}$ & $2.9 \mathrm{ab}$ & $3 a b$ & $2.6 \mathrm{c}$ & $2.4 \mathrm{c}$ & $1.7 \mathrm{~d}$ & $2.5 \mathrm{c}$ & $2.0 \mathrm{~d}$ & $2.2 \mathrm{c}$ \\
\hline 13 & Pasuruan & $3.0 \mathrm{a}$ & $2.9 \mathrm{a}$ & $1.5 \mathrm{~b}$ & $1.4 \mathrm{~b}$ & $1.5 \mathrm{~b}$ & $1.6 \mathrm{~b}$ & $1.7 \mathrm{ab}$ & $1.4 \mathrm{c}$ & $1.3 \mathrm{~d}$ & $1.3 \mathrm{~d}$ & $1.3 \mathrm{c}$ \\
\hline 14 & Nermada & $2.7 \mathrm{ab}$ & $2.3 b$ & $2.4 \mathrm{a}$ & $2.2 \mathrm{bc}$ & $2.5 \mathrm{bc}$ & $1.9 \mathrm{~d}$ & $1.9 \mathrm{e}$ & $2.2 \mathrm{c}$ & $1.8 \mathrm{f}$ & $1.6 \mathrm{~g}$ & $1.7 \mathrm{~g}$ \\
\hline 15 & Citayam & $2.4 \mathrm{ab}$ & $2.9 \mathrm{a}$ & $2.8 \mathrm{a}$ & $1.6 \mathrm{ab}$ & $2.8 \mathrm{a}$ & $1.6 \mathrm{c}$ & $2.5 \mathrm{ab}$ & $2.5 \mathrm{ab}$ & $2.6 a b$ & $1.9 \mathrm{c}$ & $2.1 \mathrm{~b}$ \\
\hline 16 & Sleman & $1.9 \mathrm{a}$ & $2.0 \mathrm{a}$ & $1.7 \mathrm{ab}$ & $1.4 \mathrm{ab}$ & $1.7 \mathrm{ab}$ & $1.9 \mathrm{a}$ & $1.5 \mathrm{ab}$ & $1.6 a b$ & $1.7 \mathrm{ab}$ & $1.3 \mathrm{~b}$ & $1.3 \mathrm{~b}$ \\
\hline
\end{tabular}

Keterangan G1 = PsJ S-30, G2 = PsJ S- 31, G3= PsJ S-32, G5= PsJ-6, G6= PsJ-19, G7= PsJ-21 G8 = PsJ-BII-17, G9= PsJ-BII-5, G10= PsJ-BII-15, G11= Gelatik, G12= Perkutut

Berdasarkan nilai $I j$, maka lokasi Nermada (NTB) dan Lombok Timur serta jambe gede Malang dinilai paling produkif (Tabel 5). mampu berdaya hasil hingga 2.47 dan 2.25 $\mathrm{t} / \mathrm{h}$ lebih tinggi dibandingkan dengan hasil varietas kacang hijau Gelati dan perkutut. 
Peningkatan hasil di atas $10 \%$ berkriteria sangat bagus. Potensi hasil suatu galur diartikan sebagai kemampuan hasil biji tertinggi yang dicapai oleh galur bersangkutan pada suatu lokasi. Interaksi G $\times$ E yang nyata (Tabel 2) mengisyaratkan perlunya menilai stabilitas hasil dari setiap galur yang diuji. Sidik ragam stabilitas sembilan galur mutan harapan kacang hijau pada 16 lokasi diperoleh interaksi antara galur dengan lokasi (linier) nyata untuk hasil biji mengindikasikan bahwa diantara galur memiliki potensi hasil yang berbeda. Interaksi antara galur dengan lingkungan (linier) yang nyata menunjukkan adanya perbedaan genetik diantara galur dan peningkatan hasil nyata dengan peningkatan produktivitas lingkungan, atau terdapat perbedaan koefisien regresi (bi) diantara galur yang diuji.

Tabel 7 menunjukkan galur mutan kacang hijau PsJ S-31 dan PsJ S-32; PsJ-6; PsJ-BII-17 dan PsJ-BII stabil pada semua lingkungan dengan rerata produksi 2.,47; 2,$25 ; 2,01 ; 2,05$ dan 2,04 ton/ha lebih tinggi dari varietas Gelatik 1.76 ton/ha (kontrol Induk) dan Perkutut 1,90 ton/ha (kontrol nasional). Galur mutan PsJ S-30; PsJ-19; PsJ -
21 dan PsJ-BII-15 BII tidak stabil pada semua lingkungan dengan rerata produksi lebih tinggi dari varietas Gelatik dan Perkutut. Varietas Gelatik dan Perkutut stabil pada semua lingkungan dengan rerata produksi lebih kecil dibandingkan dengan semua galur mutan kacang hijau.

Menurut penafsiran Finlay dan Wilkinson [14] dari nilai koefisien regresi dan rata-rata hasil ke sembilan galur mutan yang diuji (Tabel 7) dapat diketahui bahwa galur mutan PsJ S-31 memiliki daya adaptasi yang luas di lingkungan pengujian karena memiliki nilai koefisien regresi bi sama atau tidak berbeda nyata dengan satu $(b \mathbf{i} \approx 1)$ dan rata-rata hasilnya di atas rata-rata umumnya. Hal ini berarti bahwa galur tersebut dapat dibudidayakan pada berbagai lingkungan pengujian, baik di tanah sawah maupun di lahan tegalan pada musim kemarau maupun musim hujan. Selanjutnya, jika mempertimbangkan rerata hasil dan nilai bigenotipe, genotipe galur mutan PsJ S-31 memiliki daya hasil lebih tinggi dari rerata hasil seluruh galur di enambelas lokasi dan diikuti oleh nilai bi yang mendekati atau tidak berbeda nyata dengan satu dan simpangan regresi yang tidak berbeda nyata

Tabel 7. Rerata produktivitas hasil analisis gabungan uji adaptasi dan stabilitas hasil galur mutan harapan beserta varietas kontrol di 16 lokasi

\begin{tabular}{lcccl}
\hline $\begin{array}{c}\text { Galur/ } \\
\text { Varietas }\end{array}$ & Produksi (t/ha) & bi & Sd $_{\mathrm{i}}$ & \multicolumn{1}{c}{ Ket. } \\
\hline PsJ S-30 & $2,17 \mathrm{bc}$ & $0,55^{*}$ & $0,51 \mathrm{tn}$ & Tidak Stabil \\
PsJ S- 31 & $\mathbf{2 , 4 7} \mathbf{~ a ~}$ & $\mathbf{1 , 1 0 ~ t n}$ & $\mathbf{0 , 2 1} \mathbf{~ t n}$ & Stabil \\
PsJ S-32 & $2,25 \mathrm{~b}$ & $1,12 \mathrm{tn}$ & $0,26 \mathrm{tn}$ & Stabil \\
PsJ-6 & $2,01 \mathrm{~cd}$ & $1,14 \mathrm{tn}$ & $0,28 \mathrm{tn}$ & Stabil \\
PsJ-19 & $2,18 \mathrm{bc}$ & $1,19^{*}$ & $0,21 \mathrm{tn}$ & Tidak Stabil \\
PsJ-21 & $2,00 \mathrm{~d}$ & $1,22^{*}$ & $0,33 \mathrm{tn}$ & Tidak Stabil \\
PsJ-BII-17 & $2,05 \mathrm{~d}$ & $0,82 \mathrm{tn}$ & $0,33 \mathrm{tn}$ & Stabil \\
PsJ-BII-5 & $2,04 \mathrm{~d}$ & $0,95 \mathrm{tn}$ & $0,28 \mathrm{tn}$ & Stabil \\
PsJ-BII-15 & $2,12 \mathrm{c}$ & 1,23 & $0,19 \mathrm{tn}$ & Tidak Stabil \\
Gelatik & $1,76 \mathrm{e}$ & $0,85 \mathrm{tn}$ & $0,30 \mathrm{tn}$ & Stabil \\
Perkutut & $1,90 \mathrm{de}$ & $1,07 \mathrm{tn}$ & $0,17 \mathrm{tn}$ & Stabil \\
\hline
\end{tabular}

Keterangan : Angka yang diikuti diikuti oleh huruf yang tidak sama dalam suatu kolom adalah berbeda nyata berdasarkan uji DMRT 5\%

Untuk bi ${ }^{*}=$ berbeda nyata dengan 1 ;

tn $=$ tidak berbeda nyata dengan 1 .

Untuk s${ }_{\text {di: }}^{2}$ tn $=$ tidak berbeda nyata dengan 0 
dengan nol karenanya galur mutan tersebut tergolong stabil dan berpeluang adaptif pada sembarang lingkungan (Tabel 7).

Hal ini berarti galur mutan PsJ S-31 dan PsJ S-32 yang diuji stabil dan memiliki daya adaptasi yang baik pada enam belas lokasi percobaan. Terdapat empat galur mutan yang memiliki nilai $b$ i sama atau tidak berbeda nyata dengan satu $(b \mathrm{i} \approx 1)$ namun rerata hasilnya di bawah rerata umum, galur tersebut adalah PsJ S-32, PsJ 6, PsJ B-17 dan PsJ BII-5. Galur galur ini beradaptasi baik di semua lingkungan tetapi daya produksinya rendah.

Nilai koefisien regresinya tidak hanya semata-mata bertindak sebagai ukuran stabilitas, namun lebih bermanfaat untuk menilai respon suatu galur terhadap perubahan kualitas lingkungan $[25,26]$. Maksudnya, produktivitas hasil biji setiap galur akan paralel dengan peningkatan kualitas lingkungan. hubungan ini stabilitas diartikan sebagai kemampuan dari suatu genotipe untuk menghindari perubahan hasil yang besar di berbagai lingkungan [27]. Pada metode ini, model regresi adalah deskriptif linier. Penilaian dengan teknik regresi diantaranya dilakukan pada kacang hijau dan kacang tanah [28].

Hasil analisis sidik ragam gabungan dari 11 genotipe yang diuji di enam belas lokasi (Tabel 8) tidak banyak menunjukkan perbedaan yang signifikan terhadap beberapa sifat agronomi dari masing-masing galur yang diuji. Karakter tinggi tanaman galur PsJ S-32 adalah $58.84 \mathrm{~cm}$ nyata berbeda lebih pendek dibandingkan dengan varietas perkutut yang hanya $52.65 \mathrm{~cm}$ (Tabel 5). Wirnas et al. (2006) [29] menyatakan bahwa karakter tinggi tanaman tidak dapat dijadikan karakter seleksi.

Berat 100 biji galur mutan PsJ S-31 adalah 6.75 gr lebih tinggi dan berbeda

Tabel 8. Sifat agronomi galur mutan harapan beserta varietas kontrol di 16 lokasi.

\begin{tabular}{|c|c|c|c|c|c|c|c|}
\hline No. & $\begin{array}{c}\text { Galur/ } \\
\text { Varietas }\end{array}$ & $\begin{array}{l}\text { T.Tan. saat } \\
\text { Panen }(\mathrm{cm})\end{array}$ & $\begin{array}{c}\text { Umur } \\
\text { Berbunga } \\
\text { (hari) }\end{array}$ & $\begin{array}{c}\text { Umur } \\
\text { Panen } \\
\text { (hari) }\end{array}$ & $\begin{array}{l}\text { Jmlh. } \\
\text { Polong } \\
\text { (bh) }\end{array}$ & $\begin{array}{c}\text { Panjang } \\
\text { Polong } \\
(\mathrm{cm})\end{array}$ & $\begin{array}{c}\text { Berat } \\
100 \text { Biji } \\
\text { (g) }\end{array}$ \\
\hline 1 & PsJ S-30 & $60.5 \mathrm{a}$ & $36.67 \mathrm{a}$ & $60.5 \mathrm{c}$ & 15.6 cde & $10.2 \mathrm{ab}$ & $7.0 \mathrm{ab}$ \\
\hline 2 & PsJ S- 31 & $58.8 \mathrm{ab}$ & $36.0 \mathrm{ab}$ & $60.8 \mathrm{~b}$ & $15.9 \mathrm{~cd}$ & $9.2 \mathrm{ab}$ & $6.8 \mathrm{~b}$ \\
\hline 3 & PsJ S-32 & $53.5 \mathrm{~d}$ & $36.3 \mathrm{ab}$ & $56.8 \mathrm{e}$ & $15.3 \mathrm{de}$ & $9.2 \mathrm{ab}$ & $6.6 \mathrm{~d}$ \\
\hline 4 & PsJ-6 & 59.1 a & $36.0 \mathrm{ab}$ & $60.0 \mathrm{~d}$ & $17.5 \mathrm{a}$ & $9.2 \mathrm{ab}$ & $7.0 \mathrm{a}$ \\
\hline 5 & PsJ-19 & $57.1 \mathrm{bc}$ & $35.0 \mathrm{~b}$ & $59.8 \mathrm{~d}$ & $16.6 \mathrm{abc}$ & $9.1 \mathrm{ab}$ & $7.0 \mathrm{a}$ \\
\hline 6 & PsJ-21 & $56.7 \mathrm{c}$ & $36.3 \mathrm{ab}$ & $60.5 \mathrm{c}$ & $16.3 \mathrm{bcd}$ & $9.0 \mathrm{~b}$ & $6.9 \mathrm{ab}$ \\
\hline 7 & PsJ-BII-17 & $58.7 \mathrm{ab}$ & $36.3 \mathrm{ab}$ & $61.1 \mathrm{~b}$ & $15.0 \mathrm{e}$ & $9.3 \mathrm{ab}$ & $6.8 \mathrm{~b}$ \\
\hline 8 & PsJ-BII-5 & $56.6 \mathrm{c}$ & $36.3 \mathrm{ab}$ & $60.8 \mathrm{bc}$ & $16.1 \mathrm{~cd}$ & $8.9 \mathrm{ab}$ & $6.3 \mathrm{e}$ \\
\hline 9 & PsJ-BII-15 & $56.7 \mathrm{c}$ & $36.3 \mathrm{ab}$ & $59.9 \mathrm{~d}$ & $17.3 \mathrm{ab}$ & $10.6 \mathrm{ab}$ & $6.6 \mathrm{c}$ \\
\hline 10 & Gelatik & $52.6 \mathrm{~d}$ & $35.3 \mathrm{~b}$ & $59.7 \mathrm{~d}$ & $15.8 \mathrm{de}$ & $8.6 \mathrm{~b}$ & $5.5 \mathrm{c}$ \\
\hline 11 & Perkutut & 59.9 a & $36.3 \mathrm{ab}$ & $62.4 \mathrm{a}$ & $16.4 \mathrm{abcd}$ & $11.2 \mathrm{a}$ & $6.1 \mathrm{f}$ \\
\hline \multicolumn{2}{|c|}{ Rerata } & 57.3 & 36.1 & 60.21 & 16.14 & 9.50 & 6.6 \\
\hline \multicolumn{2}{|c|}{ KK (\%) } & 18.71 & 16.19 & 11.62 & 16.01 & 21.61 & 14.65 \\
\hline
\end{tabular}

Keterangan: Angka yang diikuti oleh huruf yang tidak sama dalam suatu kolom adalah berbeda nyata berdasarkan uji DMRT 5\%.

Mekanisme stabilitas secara umum dapat dikelompokkan ke dalam empat hal, yaitu heterogenitas genetik, kompensasi komponen hasil, ketenggangan terhadap deraan (stress tolerance) dan daya pemulihan yang cepat terhadap penderaan. Dalam sangat nyata dibandingkan berat 100 butir varietas Gelatik yang hanya 5.54 gr dan Perkutut (6.09 gr). Hal ini menunjukkan Mutasi Induksi dapat meningkatkan hasil berdasarkan komponen hasil berat 100 biji. Berdasarkan penampilan sifat agronomi dan 
hasil, galur galur yang termasuk stabil PsJS31, PsJS-32, PsJ6, PsJ-BII-17, PsJ-BII-5 dapat mempunyai keragaan sifat yang berbeda dari induknya (Gelatik). Galur PsJS-31 mempunyai penampilan panjang polong sangat nyata berbeda lebih panjang dari induknya (Gelatik). Umur berbunga dan umur panen galur mutan PsJS-31 (36.00 hari dan 60.83 hari nyata berbeda lebih tinggi dibanding induknya varietas gelatik (35.33 dan 59.72 hari).

\section{KESIMPULAN}

1. Diantara 9 galur mutan harapan kacang hijau yang diteliti, 5 galur mutan mempunyai daya adaptasi yang baik untuk semua lokasi pengujian, sedangkan 4 galur lainnya hanya beradaptasi baik pada lokasi tertentu.

2. Diperoleh 5 galur mutan harapan kacang hijau yang mampu beradaptasi di semua lokasi, hanya 2 yang produksinya diatas rerata keseluruhan, yaitu Galur PsJ S-31 dan PsJ S-32 sedang yang 3 galur mutan lainnya produksinya di bawah rerata galur mutan lainnya.

3. Galur PsJ S-31 memiliki nilai bi yang tidak berbeda nyata dengan 1 , sehingga tergolong galur yang stabil. Dengan melihat rataan produksinya, PsJ S-31 adalah galur yang stabil dengan produksi paling tinggi di atas rata-rata umum, sedangkan galur kontrol induk varietas Gelatik tergolong galur yang stabil dengan produksi di bawah rataan umum. Galur mutan harapan kacang hijau PsJ S31 mempunyai rerata hasil tertinggi di enam belas lingkungan pengujian yaitu 2,47 ton/ha. Galur harapan Kacang Hijau PsJ S-31 stabil di semua lokasi, dengan nilai bi 1,10 sehingga diidentifikasi mampu beradaptasi baik pada segala lingkungan produktif. Galur mutan harapan PsJ S-31 telah dilepas sebagai varietas baru dengan nama MURI.

\section{UCAPAN TERIMA KASIH}

Kami mengucapkan terima kasih kepada PAIR BATAN dan Kemenristek yang telah mendanai penelitian ini. Balai Pengawasan dan Sertifikasi Benih Departemen Pertanian yang telah bekerjasama dengan Pusat Aplikasi Isotop dan Radiasi, Badan Tenaga Nuklir Nasional (BATAN) untuk uji adaptasi galur mutan kacang hijau dari PAIR-BATAN dan tak lupa kami mengucapkan terima kasih kepada teman-teman yang telah membantu terlaksanaya penelitian ini, yaitu Bapak Nana Supriatna SP, Bapak Sihono SP dan Bapak Munata.

\section{DAFTAR PUSTAKA}

1. Badan Pusat Statistik (BPS), 2012. www bps.go.id/tnm_pgnphp

2. ASTANTO KASNO, Kacang Hijau Alternatif yang Menguntungkan Ditanam di Lahan Kering. Tabloid Sinar Tani, 23 Mei 2007. Jakarta

3. FAO/IAEA, Mutation News Letter No. 46, May, 79 (2003).

4. KIM. Alterations in the photosynthetic pigments and antioxidant machineries of red pepper (Capsicum annuum L.) seedlings from gamma-irradiated seeds. $J$. Plant Biol, 47, 314-321 (2004).

5. JAIN, M.S. Mutagenesis in crop improvement under the climate change. Rom. Biotechnol. Lett. 15, 88- 106 (2010).

6. MUDIBU, J., K.K.C. NKONGOLO, A. KALONJI-MBUYI, and V.K. ROGER. Effect of gamma irradiation on morpho- agronomic characteristics of soybean soybean (Glycine max L.). Am. J. Plant Sci. 3, 331 (2012). 
7. YULIASTI, NANA SUPRIATNA, SUDARSONO, SIHONO dan RIYANTI SUMONGGONO. Proposal Pelepasan Galur Mutan Harapan Kacang Hijau PsJ S-31 Berdaya Hasil Tinggi, Toleran Kekeringan dan Agak Tahan Terhadap Penyakit Cercospora dan Embun Tepung. PAIR BATAN Jakarta (2013).

8. BROWN KD, ME SORRELLS and WR COFFMAN. A method for classification and evaluation of testing environments. Crop Sci. 23, 889-893 (1983).

9. ALGHAMDI SS. Yield stability of some soybean genotypes across diverse environments. Pakistan J. of Biological Sci. 7, 2109-2114 (2004).

10. WIRNAS. D., Pemilihan karakterseleksi berdasarkan biometrik dan molekuler untuk merakit kedelai intensitas cahaya rendah. Disertasi IPB (2007).

11. BAYE, T.M., T. ABEBE, R.A. WILKE. Genotypeenvironment interactions and their translational implications. Per. Med., 8, 5 -70 (2011).

12. ASAD, M.A., H.R. BUGHIO, I.A. ODHANO, M.A. ARAIN, M.S. BUGHIO. Interactive effect of genotype and environment on the paddy yield in Sinh Province. Pak. J. Bot., 41, 1775-177 (200).

13. FARSHADFAR E., M.M. POURSIAHBIDI, M. JASEMI. Evaluation of phenotypic stability in bread wheat genotypes using GGEbiplot. Intl. J. Agri. Crop. Sci., 4, 0410 (2012).

14. FINLAY, K.W. and WILKINSON, G.N., The analysis of adaptation in plant breeding program. Aust. J. Agric. Res., 13, 742-754 (1963).
15. MUT, Z., A. GÜLÜMSER, A. SIRAT. Comparison of stability statistics for yield in barley (Hordeum vulgare L.). Afr. J. Biotechnol., 1610-1618 (2010).

16. RASYAD, A., IDWAR. Interaksi genetik $\mathrm{x}$ lingkungan dan stabilitas komponen hasil berbagai genotipe kedelai di Provinsi Riau. J. Agron. Indonesia, 38, 25-29 (2010).

17. KAYA Y., PALTA and S. TANER. Additive main effects and multiplicative interactions analysis of yield performances in bread wheat genotypes across environments. Turk J. Agric For. 26, 275-279 (2002).

18. H NGALAMU T., S. MESEKA and M. ASHRAF. Performance of soybean genotypes under different planting dates in Sudan. J. Appl. Biosci. 33633370 . http:// www.m.elewa.org/JABS/2012/49/8.p df (akses 11 April 2012) (2012).

19. ASFAW, A., F. GURUM, F. ALEMAYEHU, dan Y. REZENE. Analysis of multi-environment grain yield trials in mungbean Vigna radiata (L.) Wilzek based on GGE biplot in Southern Ethiopia. J. Ag. Sci. Tech., 14, 389-398 (2012).

20. TRUSTINAH dan RUDI ISWANTO, Pengaruh Interaksi Genotipe dan Lingkungan terhadap Hasil Kacang Hijau. Penelitian Pertanian Tanaman Pangan, 32 (1), 13. (2013).

21. TITIK SUNDARI, NOVITA NUGRAHAENI, dan GATUT WAHYU ANGGORO SUSANTO. Interaksi Genotipe $\mathrm{x}$ Lingkungan dan Stabilitas Hasil Biji Kedelai Toleran Naungan, J. Agron. Indonesia, 44 (1), 16-25 (2016). 
22. THANKI,

H.P., S.L. SAWARGAONKAR, B.V. HUDGE. Genotype $\mathrm{x}$ environment interaction for biometrical traits in pigeonpea (Cajanus cajan L. Millsp.) under varying spacings. Elec. J. Plant Breed. 1, 925-928 (2010).

23. ALGHAMADI SS., Yield stability of some soybean genotypes across diverse environments Pakistan, J. of Biology Sci., 7, 2109-2114 (2004).

24. ABBAS, G., B. MANZOOR, T. MAHMOOD, M. SIDDIQUE and H.M. AHSANUL, Stability analysis for seed yield in Mungbean [Vigna radiata (L.) Wilczek]., J. Agri. Res. 46 (3), 223-228 (2008).

25. TUKAMUHABWA P., H. OLOKA, T. SENGOOBA and P. KABAYI. Yield stability of rust-resistant soybean lines at four midaltitude tropical locations. Euphytica, 183 (1), 1-10. (2012).

26. DEWI AZRI, M.A CHOSIN, HERMANU TRIWIDODO, HAJRIAL ASWIDINOOR. Genotype $\mathrm{x}$ environment Interaction and stability analysis in lowland rice promising geneotypes International Journal of Agronomy and Agricultural Research (IJAAR), ISSN: 2223-7054, 5 (5), 74-84 (2014).

27. REDDY JN, CHAUDHARY D. Stability for grain yield and its components in rice. Oryza, 28, 295-299. (1991).

28. APARNA RATURI, S.K. SINGH, VINAY SHARMA and RAKESH PATHAK BANASTHALI VIDYAPEETH, BANASTHALI, RAJASTHAN., Stability and Environmental Indices Analyses for Yield Attributing Traits in Indian Vigna radiata Genotypes under Arid Conditions 1Central Arid Zone Research Institute, Jodhpur-342003. Rajasthan, India Asian J. Agric. Sci., 4 (2), 126-133 (2012).

29. WIRNAS D, WIDODO I, TRIKOESOEMANINGTYAS, SOBIR, SOEPANDI D. Pemilihan karakter Agronomi untuk menyusun indeks seleksi pada populasi Kedelai generasi F6. Bull Agronomi, XXX IV, (1) 19-24. (2006). 